\title{
Meckel Gruber Syndrome: occurrence in non-consanguineous marriages
}

\section{MVC de Silva ${ }^{1}$, H Senanayake $^{2}$ and KDVP Siriwardana ${ }^{3}$}

(Index word: Meckel Gruber syndrome)

\begin{abstract}
Meckel Gruber syndrome is an uncommon, lethal, autosomal recessive disorder, associated consistently with polycystic kidneys, posterior encephalocoele and polydactly. We report three cases in non-consanguineous marriages, suggesting that the single gene defect occurs more commonly in non-consanguineous marriages than mutant genes associated with other autosomal recessive disorders that are usually related with consanguineous marriages. The usefulness of prenatal diagnosis is discussed.
\end{abstract}

\section{Introduction}

Congenital polycystic kidneys occur due to a variety of causes such as autosomal recessive or autosomal dominant polycystic kindney disease, cystic renal dysplasia and lower urinary tract obstruction. Correct diagnosis is essential for appropriate management. Meckel Gruber syndrome is also associated consistently with polycystic kidneys [1]. Awareness and diagnosis of this syndrome will enable counselling of parents regarding the $25 \%$ recurrence risk.

\section{Case reports}

The clinical features and necropsy findings are given in Table 1. All three foetuses were products of nonconsanguineous marriages. Only the sibling of case $2 \mathrm{had}$ limb deformities and a posterior encephalocoele, and died seven days after birth. A necropsy examination was not done. An ultrasound scan done at 17 weeks of gestation in case 2 showed an abnormal skull shape and dilated lateral ventricles.

All three foetuses had posterior encephalocoeles (Figure 1) and polycystic kidneys (Figure 2), and two had polydactyly. In all three the renal cysts involved the cortex and medulla. All three had hypoplastic lungs and Potter's facies (Figure 1) comprising a sloping forehead, beakshaped nose and micrognathia. Case 1 had a right-sided aortic arch.

\section{Discussion}

Infants with Meckel Gruber syndrome die soon after or within a few days of birth or survive at the most a few weeks. Death is usually due to renal defects or nervous system abnormalities [2]. Other abnormalities described

Table 1. Clinical features and necropsy findings

\begin{tabular}{lclccllll}
\hline Parity & $\begin{array}{l}\text { Gestational } \\
\text { age* }\end{array}$ & Sex & $\begin{array}{c}\text { Birth } \\
\text { weight } \\
\text { (grams) }\end{array}$ & $\begin{array}{c}\text { Age at } \\
\text { death } \\
\text { (hours })\end{array}$ & CNS anomalies & $\begin{array}{l}\text { Kidney } \\
\text { anomalies }\end{array}$ & $\begin{array}{l}\text { Limb } \\
\text { defects }\end{array}$ & $\begin{array}{l}\text { Liver } \\
\text { anomalies }\end{array}$ \\
\hline $1 \mathrm{P}_{1} \mathrm{C}_{0}$ & 32 & Male & 2230 & One & $\begin{array}{l}\text { Posterior } \\
\text { encephalocoele } \\
\text { holoprosencephaly }\end{array}$ & $\begin{array}{l}\text { Polycystic } \\
\text { kidneys }\end{array}$ & Polydactyly & None \\
$2 \mathrm{P}_{2} \mathrm{C}_{0}$ & 34 & Female & 2000 & Stillbirth & $\begin{array}{l}\text { Posterior } \\
\text { encephalocoele }\end{array}$ & $\begin{array}{l}\text { Polycystic } \\
\text { kidneys }\end{array}$ & None & None \\
$3 \mathrm{P}_{1} \mathrm{C}_{0}$ & 34 & Female & 1800 & $<1$ & $\begin{array}{l}\text { Posterior } \\
\text { encephalocole }\end{array}$ & $\begin{array}{l}\text { Polycystic } \\
\text { kidneys }\end{array}$ & Polydactyly & $\begin{array}{l}\text { Fibrotic } \\
\text { liver }\end{array}$ \\
\hline
\end{tabular}

*Expressed as period of amenorrhoea, CNS $=$ Central Nervous System

${ }^{1}$ Senior lecturer, Department of Pathology, ${ }^{2}$ Senior lecturer, Department of Obstetrics and Gynaecology, and ${ }^{3}$ Research assistant, Department of Pathology, Faculty of Medicine, University of Colombo.

Correspondence: MVC de S, Tel: +94 11 2645575, +94 11 0777550157, e-mail: chandudesilva@yahoo.co.uk (Competing interests: none declared). Received 23 June and accepted 24 June 2003. 


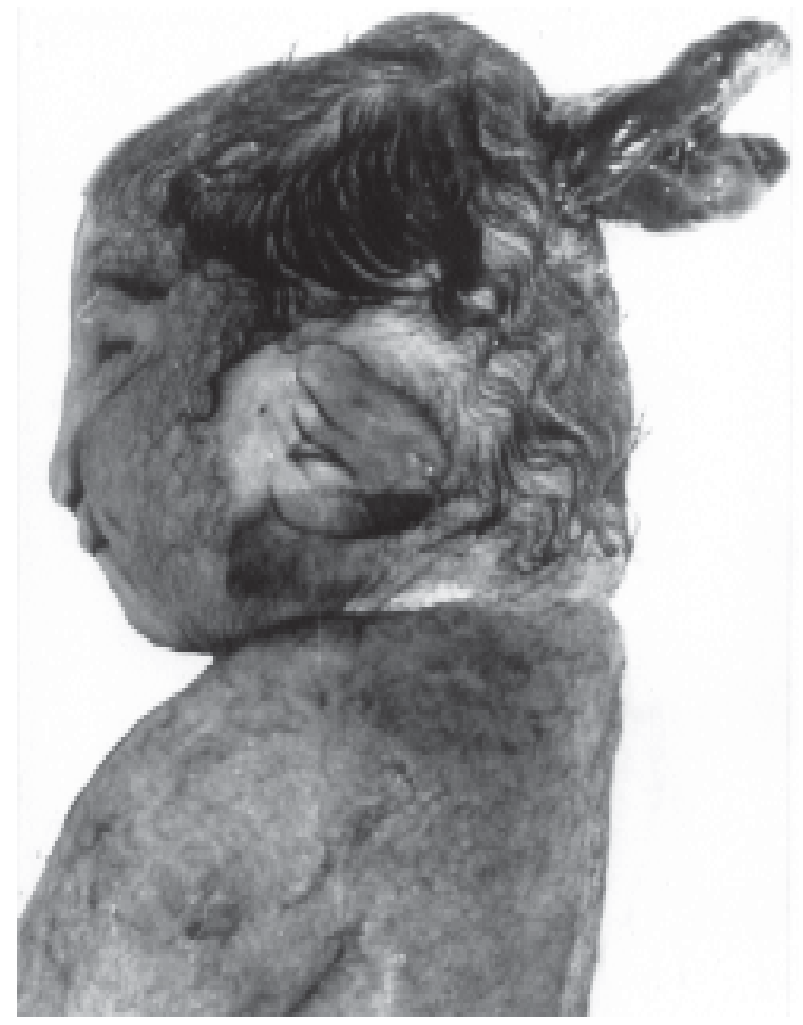

Figure 1. Case 2: Posterior encephalocoele and Potter's facies.

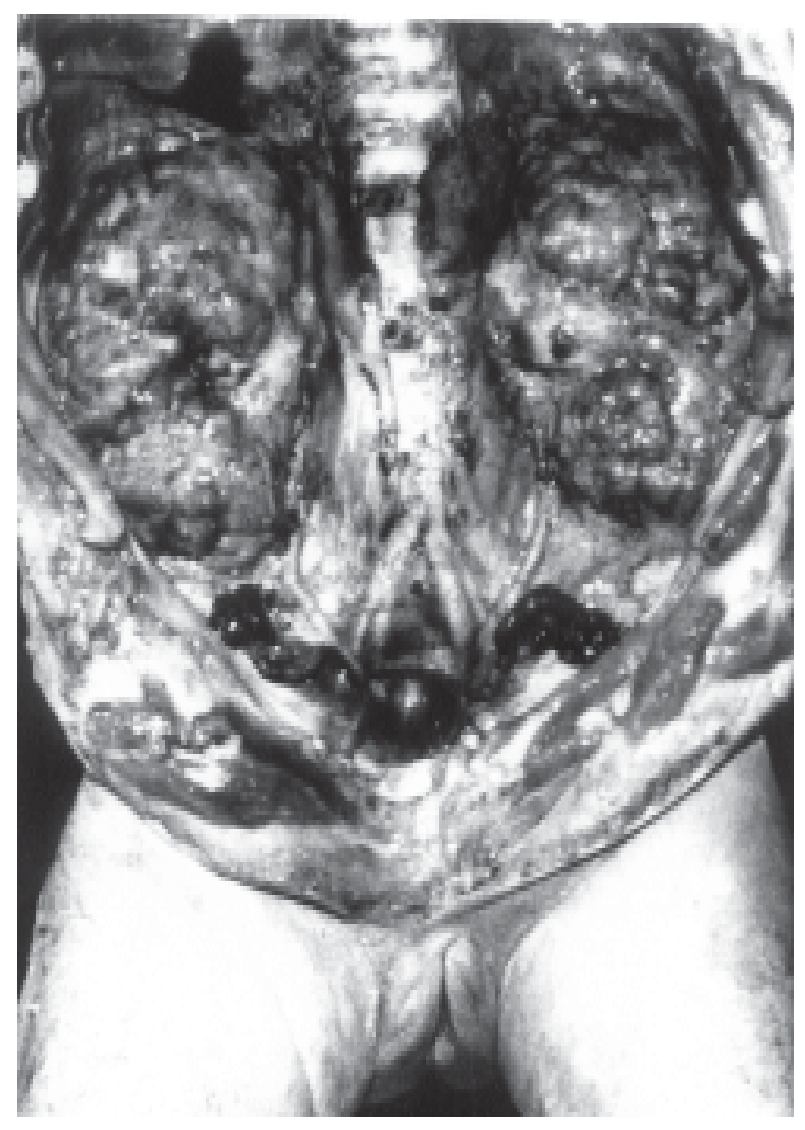

Figure 2. Case 2: Cystic kidneys. include fibrosis of liver, cerebellar hypopalasia, holoprosencephaly, and Arnold-Chiari and DandyWalker malformations [2, 3]. Although malformations of the cardiovascular system such as septal defects, pulmonary stenosis, patent ductus arteriosus and coarctation of the aorta have been reported previously [2], the occurrence of a right-sided aortic arch (case 1) has not been reported.

Although Meckel Gruber syndrome has been reported in consanguineous marriages [4] it is also known to occur in children from non-consanguineous marriages [5] suggesting that the single gene defect occurs more commonly in the latter population than mutant genes associated with other autosomal recessive disorders that are usually related with consanguineous marriages.

This condition can be suspected when there is an elevated alpha fetoprotein level together with a sonographic diagnosis of oligohydramnios associated with encephalocoele, enlarged kidneys and polydactyly at 11 to 14 weeks $[6,7]$. Prenatal diagnosis will enable the parents to consider termination of pregnancy. Even if abortion is illegal, unnecessary caesarian section can be avoided if the diagnosis is known. Postnatally, once the syndrome is recognised, parents should be offered the choice of no medical intervention for the infant. Neonates who die due to encephalocoele and polydactyly should be subjected to necropsy examination to detect the presence of polycystic kidneys. In the ensuing pregnancies prenatal diagnosis must be attempted late in the first trimester [7], since second trimester diagnosis is made difficult by the development of oligohydramnios.

\section{References}

1. Keeling JW, Boyd PA. Congenital malformations, prenatal diagnosis and fetal examination. In: Keeling JW, ed. Fetal and neonatal pathology. 2nd edn. London: SpringerVerlag, 1993: 136.

2. Jones KL, Smith's Recognizable Patterns of Human Malformation, 4th edn. Philadelphia: W.B. Saunders, 1988.

3. Yapar EG, Ekici E, Dogan M, Gokman O, Meckel-Gruber syndrome concomitant with Dandy-Walker malformation: prenatal sonographic diagnosis in two cases. Clinical Dysmorphology 1996: 5: 357-62.

4. De Silva D, Suriyawansa D, Mangalika M, Samarasinghe D. Meckel Gruber syndrome - a single gene cause of recurrent neural tube defects. Ceylon Medical Journal 2001; 46: 30-1.

5. Su SL, Liu CM, Lee JN. Prenatal diagnosis of MeckelGruber syndrome case reports (abstract). Kao Hsiung I Hsueh KO Hsueh Tsa Chih 1995; 11: 127-32.

6. Nyberg DA, Hallesy D, Mahony BS, Hirsh JH, Luthy DA, et al. Meckel Gruber syndrome: Importance of prenatal diagnosis. Journal of Ultrasound Medicine 1990; 9: 691-6.

7. Sepulveda W, Sebire NJ, Souka A, Snijders RJ, Nicolaides $\mathrm{KH}$. Diagnosis of Meckel Gruber syndrome at eleven to fourteen weeks gestation. American Journal of Obstetrics and Gynecology 1997; 176: 316-9. 